\title{
The proper effect site concentration of remifentanil for prevention of myoclonus after etomidate injection
}

\author{
Hyun Su Ri, Sang Wook Shin, Tae Kyun Kim, Seung Wan Baik, Ji Uk Yoon, and Gyeong Jo Byeon \\ Department of Anesthesiology and Pain Medicine, Pusan National University School of Medicine, Yangsan, Korea
}

Background: Etomidate frequently induces myoclonus when administered intravenously with bolus injection during anesthetic induction. This can be bothersome for the anesthesiologist. The dose of remifentanil appropriate for preventing myoclonus without side effects was investigated.

Methods: All patients with American Society of Anesthesiologists (ASA) physical status I-III were divided into three groups ( $\mathrm{n}=33$ per group) according to the pretreatment effect site concentration of remifentanil (Ultiva, GlaxoWellcome, München, Germany) of 0, 2 or 4 ng/ml (Group N: 0 ng/ml, Group R: 2 ng/ml, Group Q: 4 ng/ml) by a target controlled infusion (TCI) system. After a $0.3 \mathrm{mg} / \mathrm{kg}$ dose of etomidate was injected intravenously for over 1 minute for anesthetic induction, myoclonus was observed. Before the etomidate injection, the patients were pretreated with remifentanil and their side effects were monitored.

Results: The number of patients showing myoclonus was significantly different among the groups. The incidence of myoclonus was $81 \%, 12 \%$ and $0 \%$ (groups $\mathrm{N}, \mathrm{R}$, and $\mathrm{Q}$, respectively, $\mathrm{P}<0.01$ ). Side effects including bradycardia and hypotension did not occur in either Group R or Q. Chest wall rigidity occured in $45 \%$ of patients in Group Q.

Conclusions: Administration with a $2 \mathrm{ng} / \mathrm{ml}$ effect site concentration of remifentanil could reduce the incidence of myoclonus caused by etomidate bolus injection without chest wall rigidity. (Korean J Anesthesiol 2011; 61: 127-132)

Key Words: Etomidate, Myoclonus, Remifentanil.

Received: April 30, 2010. Revised: 1st, May 24, 2010; 2nd, July 17, 2010. Accepted: January 6, 2011.

Corresponding author: Sang Wook Shin, M.D., Department of Anesthesiology and Pain Medicine, Pusan National University Yangsan Hospital, Beomeo-ri, Mulgeum-eup, Yangsan 626-770, Korea. Tel: 82-55-360-2129, Fax: 82-55-360-2149, E-mail: shinsw@pusan.ac.kr This is a theisis for a master's degree.

@ This is an open-access article distributed under the terms of the Creative Commons Attribution Non-Commercial License (http:// creativecommons.org/licenses/by-nc/3.0/), which permits unrestricted non-commercial use, distribution, and reproduction in any medium, provided the original work is properly cited. 


\section{Introduction}

Etomidate is a popular hypnotic agent, and it has a stable hemodynamic profile with minimal histamine release [1]. However, etomidate often induces spontaneous movements, especially myoclonic activity, and can enhance focal epileptogenic activity in patients with epilepsy [2]. Myoclonus has been described as the involuntary contracture of some muscle fibers, which involves a whole muscle, or different muscles of one group, leading to short observable movements of the corresponding body parts. Myoclonus is observed in $50-80 \%$ of non-premedicated patients after etomidate administration [3], and it can be a problem in patients who had open-global injury or full-stomach conditions. In patients with an open-global injury, myoclonus after etomidate administration increases the risk of vitreous prolapse because of high intraocular pressure [4].

The incidence of myoclonus can be reduced by various agents including benzodiazepines, magnesium sulfate, rocuronium and opioids [1,4-7]. Remifentanil is a selective $\mu$-receptor agonist with similar pharmacodynamic properties to other opioid receptor agonists such as fentanyl [8,9], and it is metabolized rapidly with a very short acting duration independent of infusion time. However, it can cause adverse effect like bradycardia and/or chest wall rigidity even at the low dose of $1.0 \mu \mathrm{g} / \mathrm{kg}[8,10-12]$.

The aim of this study was to investigate the safe effect site concentration of remifentanil for preventing myoclonus induced by etomidate injection without generating side effects.

\section{Materials and Methods}

The study protocol was approved by the Institutional Review Board of the Clinical Research Ethics Committee. Adult patients with American Society of Anesthesiologists (ASA) physical status I-III and who were scheduled for elective surgery under general anesthesia were selected for this study and the three groups were demographically similar (Table 1). Patients with neuropsychological disease or abnormality of the adrenal gland were excluded. Thirty minutes before Committee. Adult patients

Table 1. Demographic Data

\begin{tabular}{lccc}
\hline & $\begin{array}{c}\text { Group N } \\
(\mathrm{n}=33)\end{array}$ & $\begin{array}{c}\text { Group R } \\
(\mathrm{n}=33)\end{array}$ & $\begin{array}{c}\text { Group Q } \\
(\mathrm{n}=33)\end{array}$ \\
\hline Age (yr) & $41.9 \pm 16.7$ & $44.2 \pm 15.0$ & $42.2 \pm 18.3$ \\
Gender (M/F) & $17 / 16$ & $16 / 17$ & $16 / 17$ \\
Weight (kg) & $65.4 \pm 12.4$ & $62.8 \pm 10.9$ & $65.3 \pm 13.2$ \\
\hline
\end{tabular}

Group N: normal saline, Group R: pretreatment with $2 \mathrm{ng} / \mathrm{ml}$ of remifentanil, Group Q: pretreatment with $4 \mathrm{ng} / \mathrm{ml}$ of remifentanil. with American Society of Anesthesiologists (ASA) physical status I-III and who were scheduled for elective surgery under general anesthesia were selected for this study and the three groups were demographically similar (Table 1). Patients with neuropsychological disease or abnormality of the adrenal gland were excluded. Thirty minutes before arrival at the operating room, midazolam $0.05 \mathrm{mg} / \mathrm{kg}$ and glycopyrrolate $0.2 \mathrm{mg}$ were injected intramuscularly as premedication. Venous access with an IV canula was placed in the patient's antecubital fossa. On arrival at the operating room, patient monitors such as oxygen saturation $\left(\mathrm{SpO}_{2}\right)$ by pulse oximeter probe, electrocardiography (ECG), and a blood pressure cuff were applied. The standard bispectral index (BIS) was monitored (BIS Quatro,Aspect Medical System Inc.) by placing the electrode on the forehead of each patient and the BIS score was monitored.

The patients, who had provided written, informed consent, were allocated in a randomized fashion by sealed envelope into the 3 pretreatment groups ( $n=33$ per group) according to the effect site concentration of remifentanil (Ultiva, GlaxoWellcome, München, Germany) of 0, 2 or $4 \mathrm{ng} / \mathrm{ml}$ (Group $\mathrm{N}$ : 0 ng/ml, Group R: 2 ng/ml, Group Q: 4 ng/ml). A target controlled infusion (TCI) system for remifentanil was adopted to produce an accurate desired plasma concentration. Each effect site concentration ( 2 or $4 \mathrm{ng} / \mathrm{ml}$ ) was set by an infusion pump (Orchestra ${ }^{\circledR}$, Fresenius Vial, France) with the Minto model. The concentration of $0 \mathrm{ng} / \mathrm{ml}$ of remifentanil was set by a syringe filled with saline. BP and HR were recorded at baseline, 210 seconds after injection of etomidate $0.3 \mathrm{mg} /$ $\mathrm{kg}$, 30 seconds, $1 \mathrm{~min}$ and $3 \mathrm{~min}$ after intubation. When the SQI (signal quality index) was maintained over 90, the BIS was measured continuously throughout the procedure and recorded at baseline, the end of etomidate administration, and every 30 seconds after etomidate administration until 2 minutes. After preoxygenation for 1 minute, one of the solutions (remifentanil $50 \mu \mathrm{g} / \mathrm{ml}$ or saline) was infused through the infusion pump. Any side effects, such as cough, sedation, chest wall rigidity, or apnea, were checked by an anesthesiologist who was blinded to the groups. The Ramsay sedation scale was used for evaluating sedation and sedation was indicated by a 4 on the Ramsay sedation scale, which was no response

Table 2. Ramsay Sedation Scale

\begin{tabular}{cl}
\hline Score & \multicolumn{1}{c}{ Response } \\
\hline 1 & Anxious or restless or both \\
2 & Cooperative, orientated and tranquil \\
3 & Responding to commands \\
4 & Brisk response to stimulus \\
5 & Sluggish response to stimulus \\
6 & No response to stimulus \\
\hline
\end{tabular}

Sedation was indicated by 4 on the Ramsay sedation scale. 
to commands (Table 2). Chest wall rigidity was defined as decreased chest wall compliance to external positive ventilatory pressure. During ventilation with a mask, chest wall rigidity was monitored for improper ventilation and the increase of peak inspiratory pressure above $20 \mathrm{mmHg}$ [13]. After the effect-site concentration of remifentanil reached the target concentration, $0.3 \mathrm{mg} / \mathrm{kg}$ of etomidate (Etomidate-Lipuro, B. Braun Melsungen, Melsungen, Germany) was injected intravenously for over $1 \mathrm{~min}$, then patients were observed visually for myoclonus. When myoclonus is present, its severity was graded by an anesthesiologist who was blinded to the effect site concentration of remifentanil. Intensity of myoclonic movement was graded as 0 (none), 1 (mild; movement at the finger or wrist only), 2 (moderate; involving the face and leg), or 3 (severe; generalized response or fast abduction of the limb) $[8,11]$. Two minutes after etomidate administration, rocuronium $0.8 \mathrm{mg} / \mathrm{kg}$ was administered to facilitate tracheal intubation. After ventilation with 6 vol\% sevoflurane for 90 seconds, an endotracheal tube was intubated.

The expected incidence of myoclonus in the control group (Group N) was $80 \%$ and 28 patients were required in each group to detect a $50 \%$ difference at a $95 \%$ significance level and a power of 0.8 based on previous studies $[1,3]$. Thirty three

Table 3. Frequency and Severity of Myoclonus after Injection of Etomidate Numbers are Frequencies

\begin{tabular}{lrrc}
\hline & Group N & Group R & Group Q \\
\hline None & 6 & 29 & 33 \\
Mild & 6 & 3 & 0 \\
Moderate & 9 & 1 & 0 \\
Severe & 12 & 0 & 0
\end{tabular}

Group N: normal saline, Group R: pretreatment with $2 \mathrm{ng} / \mathrm{ml}$ of remifentanil, Group Q: pretreatment with $4 \mathrm{ng} / \mathrm{ml}$ of remifentanil. patients were included in each group. Statistical analysis was performed by SPSS 12.0 (SPSS, Chicago, IL). Comparison of demographic data was performed by one way ANOVA and the chi-square test. The incidence and severity of myoclonus were analysed by Pearson's chi-square test and linear by linear association. The changes in BP and HR over time were analyzed by repeated measures ANOVA. Results were considered statistically significant when $\mathrm{P}<0.05$.

\section{Results}

The incidence of myoclonus of each group was significantly different according to the Pearson chi-square test $(\mathrm{P}<0.01)$. The incidence of myoclonus in Groups $\mathrm{N}, \mathrm{R}$, and $\mathrm{Q}$ were $81 \%, 12 \%$, and $0 \%$, respectively $(\mathrm{P}<0.01$ ) (Table 3 ). The severity of myoclonus decreased with an increasing effect site concentration of remifentanil, which was revealed by the linear by linear association. Cough (13/33 patients), chest wall rigidity (15/33 patients), apnea (2/33 patients), and sedation (15/33 patients) occurred in Group Q. No side effects occurred

Table 4. Number of Side Effects

\begin{tabular}{lccc}
\hline & $\begin{array}{c}\text { Group N } \\
(\mathrm{n}=33)\end{array}$ & $\begin{array}{c}\text { Group R } \\
(\mathrm{n}=33)\end{array}$ & $\begin{array}{c}\text { Group Q } \\
(\mathrm{n}=33)\end{array}$ \\
\hline Cough (n) & 0 & 0 & 13 \\
Chest wall rigidity (n) & 0 & 0 & 15 \\
Apnea (n) & 0 & 0 & 2 \\
Sedation (n) & 0 & 0 & 2
\end{tabular}

Chest wall rigidity was evaluated by improper ventilation and an increase in peak inspiratory pressure over $20 \mathrm{mmHg}$ during mask ventilation. Sedationindicates a 4 on the Ramsay sedation scale. Group N: normal saline, Group R: pretreatment with $2 \mathrm{ng} / \mathrm{ml}$ of remifentanil, Group Q: pretreatment with $4 \mathrm{ng} / \mathrm{ml}$ of remifentanil.
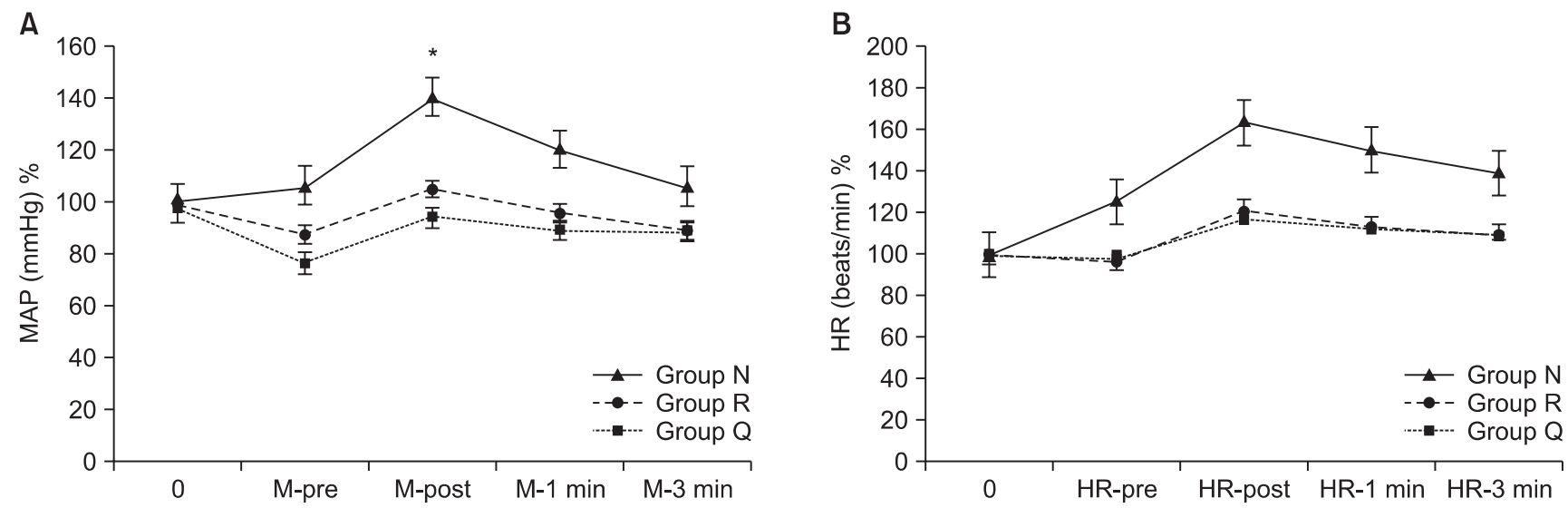

Fig. 1. The change of BP (A) and HR (B) in Group R and Group Q were lesser than that in Group N, and BP was lower in Group R and Group Q than Group N. Group N: normal saline, Group R: pretreatment with $2 \mathrm{ng} / \mathrm{ml}$ of remifentanil, Group Q: pretreatment with $4 \mathrm{ng} / \mathrm{ml}$ of remifentanil. $* \mathrm{P}<0.05$ compared to the other group. 
in groups $\mathrm{N}$ or $\mathrm{R}$ (Table 4). The changes of $\mathrm{BP}$ throughout the procedure did not differ among the groups except for the postintubation period. BP after intubation in Group N was higher than BP in the other groups $(\mathrm{P}<0.05)$ (Fig. 1). Even though it looks like there were differences in HR between groups, there was no significant difference in statistics.

\section{Discussion}

This study showed that a $2 \mathrm{ng} / \mathrm{ml}$ effect site concentration of remifentanil prevented etomidate-induced myoclonus without any side effects. The incidence of myoclonus was $82 \%$ in Group $\mathrm{N}$ and it decreased to $12 \%$ in group $\mathrm{R}$. We could not find any myoclonus in Group Q. We could compare the effect site concentration in each case using TCI. TCI allows an accurate adaptation of the analgesia level and fewer overdose-linked adverse effects. This result is compatible with previous reports utilizing other treatment $[1,3,4]$. Myoclonus occurred at least 60 seconds to 90 seconds after the end of injection and no patients expressed pain during injection. Thus we defined myoclonus differently from injection pain based on those results. Some studies have reported that 50 to $80 \%$ of patients receiving etomidate showed myoclonic activity $[3,14]$.

The neurologic mechanism of myoclonic activity after etomidate administration is not clear, but may be a kind of seizure activity [14]. Other studies suggested that myoclonus after etomidate administration is a result of temporary subcortical disinhibition like that of restless legs during sleep and does not happen from an epileptic focus $[3,15,16]$. An unsynchronized onset of etomidate induces fast depression of the cortex, resulting in temporary disinhibition of the subcortex from inducing the myoclonic movement. Thus, pretreatment with a small amount of etomidate reduces myoclonus and this suggests a support for the former mechanism [3].

The dosage of etomidate influences the incidence of myocluonus. The dosage as much as $0.05 \mathrm{mg} / \mathrm{kg}$ etomidate did not induce myoclonic activity, but a dosage above $0.075 \mathrm{mg} / \mathrm{kg}$ caused myoclonic activity in men [3].

Schwarzkopf et al. [1] suggested that midazolam $(0.5 \mathrm{mg} / \mathrm{kg})$, injected 90s before etomidate administration intravenously, reduced the incidence of myoclonus by $20 \%$. In control group of this study, however, midazolam $(0.05 \mathrm{mg} / \mathrm{kg})$ injected intramuscularly 30 minutes before etomidate administration did not reduce the incidence of myoclonus. The incidence of control group was $82 \%$ which was not differ from previously reported myoclonus incidence. The different results may stem from the dosage of midazolam and the route and timing of injection. Magnesium sulfate $(2.48 \mathrm{mmol})$ injected $90 \mathrm{~s}$ before etomidate administration intravenously, reduced the incidence of myoclonus by $76 \%$ and severity of myoclonus
[5]. Pretreatment of etomidate could reduce the incidence of myoclonus. It was suggested that myoclonus after injection of $0.3 \mathrm{mg} / \mathrm{kg}$ etomidate was less likely after pretreatment with 0.03 or $0.05 \mathrm{mg} / \mathrm{kg}$ etomidate than after pretreatment with 0.075 $\mathrm{mg} / \mathrm{kg}$ etomidate both in men and women [3]. Pretreatment of rocuronium $(0.06 \mathrm{mg} / \mathrm{kg})$ showed the incidence to be $25 \%$ [6].

Opioids could reduce the incidence of etomidate induced myoclonus. Pretreatment with alfentanil $(5 \mu \mathrm{g} / \mathrm{kg})$ resulted in an incidence of $25 \%$ [17] and fentanyl (100, 250, and $500 \mu \mathrm{g} / \mathrm{kg})$ before etomidate injection reduced the incidence of myoclonus (33\%, 13\%, and $0 \%$, respectively) but increased the incidence of apnea (87\%, 87\%, and $100 \%$, respectively) [18]. Hueter et al. [4] showed that in female patients, there were no patients who had myoclonic activity in the group premedicated with $0.3 \mathrm{mg} /$ $\mathrm{kg}$ sufentanil, but $80 \%$ of patients in the placebo group showed myoclonic activity.

Recently, remifentanil, which is a short-acting opioid, has been suggested for possibly reducing myoclonus after etomidate injection [19]. There was no study about the mechanism of remifentanil to reduce etomidate-induced myoclonus. The mechanism of fentanyl, which has similar potency, is that it stimulates $\mathrm{GABA}_{\mathrm{A}} \mu$-opioid receptors in the basal ganglia [3]. These reports are similar to ours that increasing the dose of opioids decreases the incidence of myoclonus but it increases the side effects of cough and chest wall rigidity. We could find that the side effects of remifentanil increase in Group $\mathrm{Q}$ (remifentanil $4 \mathrm{ng} / \mathrm{ml}$ ). The recommended loading bolus dose of remifentanil during induction with a hypnotic agent is $1.0 \mu \mathrm{g} / \mathrm{kg}$ [10]. Hwang et al. [20] studied pre-treatment of remifentanil: Without premedication, they injected $1.0 \mu \mathrm{g} /$ $\mathrm{kg}$ remifentanil for over $60 \mathrm{~s}$, then etomidate injection for over $10 \mathrm{~s}$, then had a 2-min observation period for myoclonus. In that study, myoclonus occurred in $17 \%$ of cases with $1.0 \mu \mathrm{g} /$ $\mathrm{kg}$ of remifentanil and a similar incidence with $0.05 \mathrm{mg} / \mathrm{kg}$ pre-treatment with midazolam, but chest wall rigidity and bradycardia occurred. Muscle rigidity and bradycardia were serious side-effects of remifentanil [8-10,21].

We cannot ensure that remifentanil is a superior agent to other drugs or opioids, but it is advantageous that remifentanil has a rapid onset and offset, it is easy to adjust the proper effect site concentration and to find the safety concentration when using a TCI system. Further evaluation comparing other agents with $2 \mathrm{ng} / \mathrm{ml}$ of remifentanil is needed in the future.

There is a limitation in the design of our study, in that we infused etomidate immediately after the effect site concentration of remifentanil reached target concentration.

Our study was planned with premedication with glycopyrrolate and midazolam to decrease upper airway secretion and for ethical reasons. We thought premedication with midazolam would have a synergic effect with remifentanil. In other studies, 
when premedication is given with benzodiazepine or fentanyl, myoclonus is reduced by inhibition of subcortical neuronal activity $[22,23]$.

In the case of this study, it was performed with a TCI pump to titrate the effect site concentration of remifentanil. In the absence of a TCI pump, a cautious bolus injection could be a substitution for the pump infusion. The effect site concentration of $4-6 \mathrm{ng} / \mathrm{ml}$ of remifentanil could be achieved by a bolus dose of $0.8-2.1 \mu \mathrm{g} / \mathrm{kg}$ if adjusted according for various ages and body weights [24]. The maximal time to the effect site concentration was about 70-100 seconds. Fifteen patients in Group Q experienced chest wall rigidity. In Group $\mathrm{R}$, the incidence of chest wall rigidity was significantly decreased and there was no other side effect.

Opioid administration during induction has often been complicated by muscular rigidity and difficult ventilation. The sequelae of difficult ventilation are clinically important and can include hypertension, hypoxemia, pulmonary hypertension, respiratory acidosis, and increased intracranial pressure [2527]. Difficult or impossible ventilation after opioid induction is commonly ascribed to rigidity of the abdominal and thoracic musculature. There has been some evidence that fiber optic visualization of the glottis revealed closed vocal cords in some; however, they also described patients who had opened vocal cords but could not be ventilated [28]. The incidence of rigidity and severities varies depending on the kinds of opioid and doses used and the rate at which it is administered. To avoid serious airway obstruction like glottic closure, cautious dosing and administration must be carried out. In the case of our study, normal ranges of end tidal carbon dioxide showed there were no cases of airway obstruction.

This study has a limitation in defining the chest wall rigidity with peak air way pressure. To obtain accurate measurements of peak airway pressure, an unintubated mask ventilation requires an excellent mask seal, proper placement of an oral airway, and the use of an aggressive jaw thrust maneuver. Delivering a tidal volume with pressure above $20 \mathrm{mmHg}$, which is considered to be the upper esophageal sphincter tone is prone to cause abdominal distension. We tried not to raise peak airway pressure above $20 \mathrm{mmHg}$; if it happened, it was considered as occurrence of chest rigidity.

We can conclude that treatment with remifentanil $2 \mathrm{ng} / \mathrm{ml}$ of effect site concentration before etomidate administration significantly reduced the frequency of myoclonic activity without side effects.

\section{References}

1. Schwarzkopf KR, Hueter L, Simon M, Fritz HG. Midazolam pretreatment reduces etomidate-induced myoclonic movements.
Anaesth Intensive Care 2003; 31: 18-20.

2. Ebrahim ZY, DeBoer GE, Luders H, Hahn JF, Lesser RP. Effect of etomidate on the electroencephalogram of patients with epilepsy. Anesth Analg 1986; 65: 1004-6.

3. Doenicke AW, Roizen MF, Kugler J, Kroll H, Foss J, Ostwald P. Reducing myoclonus after etomidate. Anesthesiology 1999; 90: 113-9.

4. Hueter L, Schwarzkopf K, Simon M, Bredle D, Fritz H. Pretreatment with sufentanil reduces myoclonus after etomidate. Acta Anaesthesiol Scand 2003; 47: 482-4.

5. Guler A, Satilmis T, Akinci SB, Celebioglu B, Kanbak M. Magnesium sulfate pretreatment reduces myoclonus after etomidate. Anesth Analg 2005; 101: 705-9.

6. Choi JM, Choi IC, Jeong YB, Kim TH, Hahm KD. Pretreatment of rocuronium reduced the frequency and severity of etomidateinduced myoclonus. J Clin Anesth 2008; 20: 601-4.

7. Kelsaka E, Karakaya D, Sarihasan B, Baris S. Remifentanil pretreatment reduces myoclonus after etomidate. J Clin Anesth 2006; 18: 83-6.

8. Joshi GP, Warner DS, Twersky RS, Fleisher LA. A comparison of the remifentanil and fentanyl adverse effect profile in a multicenter phase IV study. J Clin Anesth 2002; 14: 494-9.

9. Glass PS, Hardman D, Kamiyama Y, Quill TJ, Marton G, Donn KH, et al. Preliminary pharmacokinetics and pharmacodynamics of an ultra-short-acting opioid: remifentanil (GI87084B). Anesth Analg 1993; 77: 1031-40.

10. Bürkle H, Dunbar S, Van Aken H. Remifentanil: a novel, shortacting, mu-opioid. Anesth Analg 1996; 83: 646-51.

11. Chung F, Mulier JP, Scholz J, Breivik H, Araujo M, Hjelle K, et al. A comparison of anaesthesia using remifentanil combined with either isoflurane, enflurane or propofol in patients undergoing gynaecological laparoscopy, varicose vein or arthroscopic surgery. Acta Anaesthesiol Scand 2000; 44: 790-8.

12. Schüttler J, Albrecht S, Breivik H, Osnes S, Prys-Roberts C, Holder $\mathrm{K}$, et al. A comparison of remifentanil and alfentanil in patients undergoing major abdominal surgery. Anaesthesia 1997; 52: 307 17.

13. Bennett JA, Abrams JT, Van Riper DF, Horrow JC. Difficult or impossible ventilation after sufentanil-induced anesthesia is caused primarily by vocal cord closure. Anesthesiology 1997; 87: 1070-4.

14. Ghoneim MM, Yamada T. Etomidate: a clinical and electroencephalographic comparison with thiopental. Anesth Analg 1977; 56: 479-85.

15. Reddy RV, Moorthy SS, Dierdorf SF, Deitch RD Jr, Link L. Excitatory effects and electroencephalographic correlation of etomidate, thiopental, methohexital, and propofol. Anesth Analg 1993; 77: 1008-11.

16. Modica PA, Tempelhoff R, White PF. Pro- and anticonvulsant effects of anesthetics (part I). Anesth Analg 1990; 70: 303-15.

17. Khalil SN, Lawson KS, Hanis CL, Lemak NA, Ruiz RS. Alfentanil decreases myoclonus caused by etomidate. Middle East J Anesthesiol 1999; 15: 185-92.

18. Stockham RJ, Stanley TH, Pace NL, Gillmor S, Groen F, Hilkens P. Fentanyl pretreatment modifies anaesthetic induction with etomidate. Anaesth Intensive Care 1988; 16: 171-6.

19. Lee SW, Gill HJ, Park SC, Kim JY, Kim JH, Lee JY, et al. The effect of remifentanil for reducing myoclonus during induction of anesthesia with etomidate. Korean J Anesthesiol 2009; 57: 438-43. 
20. Hwang JY, Kim JH, Oh AY, Do SH, Jeon YT, Han SH. A comparison of midazolam with remifentanil for the prevention of myoclonic movements following etomidate injection. J Int Med Res 2008; 36: 17-22.

21. Davis PJ, Lerman J, Suresh S, McGowan FX, Cote CJ, Landsman I, et al. A randomized multicenter study of remifentanil compared with alfentanil, isoflurane, or propofol in anesthetized pediatric patients undergoing elective strabismus surgery. Anesth Analg 1997; 84: 982-9.

22. Holdcroft A, Morgan M, Whitwam JG, Lumley J. Effect of dose and premedication on induction complications with etomidate. $\mathrm{Br}$ J Anaesth 1976; 48: 199-205.

23. van Dijk B. Venous pain and involuntary muscular movements during and after administration of etomidate. A comparison of two different formulations. Anaesthesist 1978; 27: 60-3.

24. Minto CF, Schnider TW, Egan TD, Youngs E, Lemmens HJ, Gambus $\mathrm{PL}$, et al. Influence of age and gender on the pharmacokinetics and pharmacodynamics of remifentanil. I. model development. Anesthesiology 1997; 86: 10-23.

25. Benthuysen JL, Smith NT, Sanford TJ, Head N, Dec-Silver H. Physiology of alfentanil-induced rigidity. Anesthesiology 1986; 64: 440-6.

26. Mets B, James MF. Another complication of opiate-induced chest wall rigidity. S Afr Med J 1992; 81: 385-6.

27. Benthuysen JL, Kien ND, Quam DD. Intracranial pressure increases during alfentanil-induced rigidity. Anesthesiology 1988; 68: 438-40.

28. Arandia HY, Patil VU. Glottic closure following large doses of fentanyl. Anesthesiology 1987; 66: 574-5. 